\title{
フロン代替化洗浄技術の現状
}

高級アルコール系洗浄剤

千原 畺知夫*

\section{The Current Status of CFC Alternatives for Cleaning.}

\section{- Cleaning Agents Containing Higher Alcohol Derivatives.}

Machio CHIHARA *

$*$ 荒川化学工業株式会社研究部（テ538 大阪府大阪市鶴見区鶴見1-1-9）

* Research Div., Arakawa Chemical Industries, Ltd. (1-1-9, Tsurumi, Tsurumi-ku, Osaka-shi, Osaka 538)

1.はじめに

地球環境保護への関心が国際的に高まるなかで, エレクトロニクスの実装技術においても，従来のフ ロン洗浄に代わる代替技術の開発が求められている。 実装基板のフラックスの洗浄では，無洗浄化の試行 や無洗浄フラックスへの転換，あるいは水性フラッ クスに代えての水洗浄化，そしてフロンに代わる代 替洗浄剤の検討が各所で進められている。本稿では, ロジンフラックスの洗浄剤として提案されている非 ハロゲン系の代替洗浄剤を概観しながら，実装基板 の洗浄における高級アルコール系洗浄郕の特徵を述 ベる。

\section{2. 洗浄棛の特性要因}

非ハロゲン系洗浄剤の洗浄工程は，図 1 に示した ように，洗浄剤で基板上のフラックス残渣を溶解除 去した後, 水すすぎを経て乾燥するという 3 段階か ら成っている。これは，フロンと異なり洗浄剤自体 の蒸発乾燥が困難なために, 乾燥前に基板上の洗浄 剤を水に置換する必要があるからである。したがっ て, 洗浄剤の洗浄力を検討する際には, そのフラッ クス溶解力とともに，洗浄剤の水すすぎ性も重要な 要因として考慮しなければならない。特に高度な清 浄度が要求される基板では, 繰り返し使用を前提と する洗浄剤が完全にすすぎ落とせないと含まれるフ ラックス分も残留することとなり，目標の洗浄品質
を保てないおそれがある。また被洗浄物がボンディ ングなどの後加工を伴う基板の場合，フラックスを 含まない洗浄剤であっても，残留物そのものが不良 原因とも成り得る。

一方，生産ラインにおける長期の使用では，洗浄 基板の絶縁抵抗性などの信頼性，または毒性や引火 性などの安全性，さらにはすすぎ水の排水処理や洗 浄廃液の処理などの環境適性も考慮する必要がある。 図 2 に非八ロゲン系洗浄剤の特性要因図を示した。

\section{3. 洗浄刘の夕イプ}

実装基板の洗浄で洗い落とすべき対象は，ロジン フラックスの残渣である。この残渣は，ロジンや重 合ロジン，ロジン変性フェノールといったロジン誘 導体と，ジメチルアミン塩酸塩などの活性剤から成っ ている。しかし，ソルダリングの過程における熱履 歴や洗浄までの時間経過に伴って, 分解や酸化など の複雑な反応を経ていて，その洗浄性は一様ではな い。また洗浄剤の組成には，幅広い溶解性を付与し， 白色残渣の発生を抑制するための種々の工夫がなさ れているが，ここでは基本的な洗浄の仕組みと洗浄

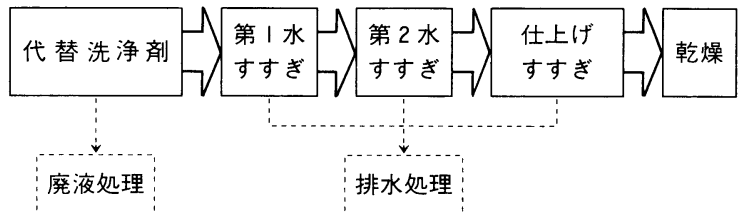

図 1. 非ハロゲン系洗浄剤の洗浄工程 


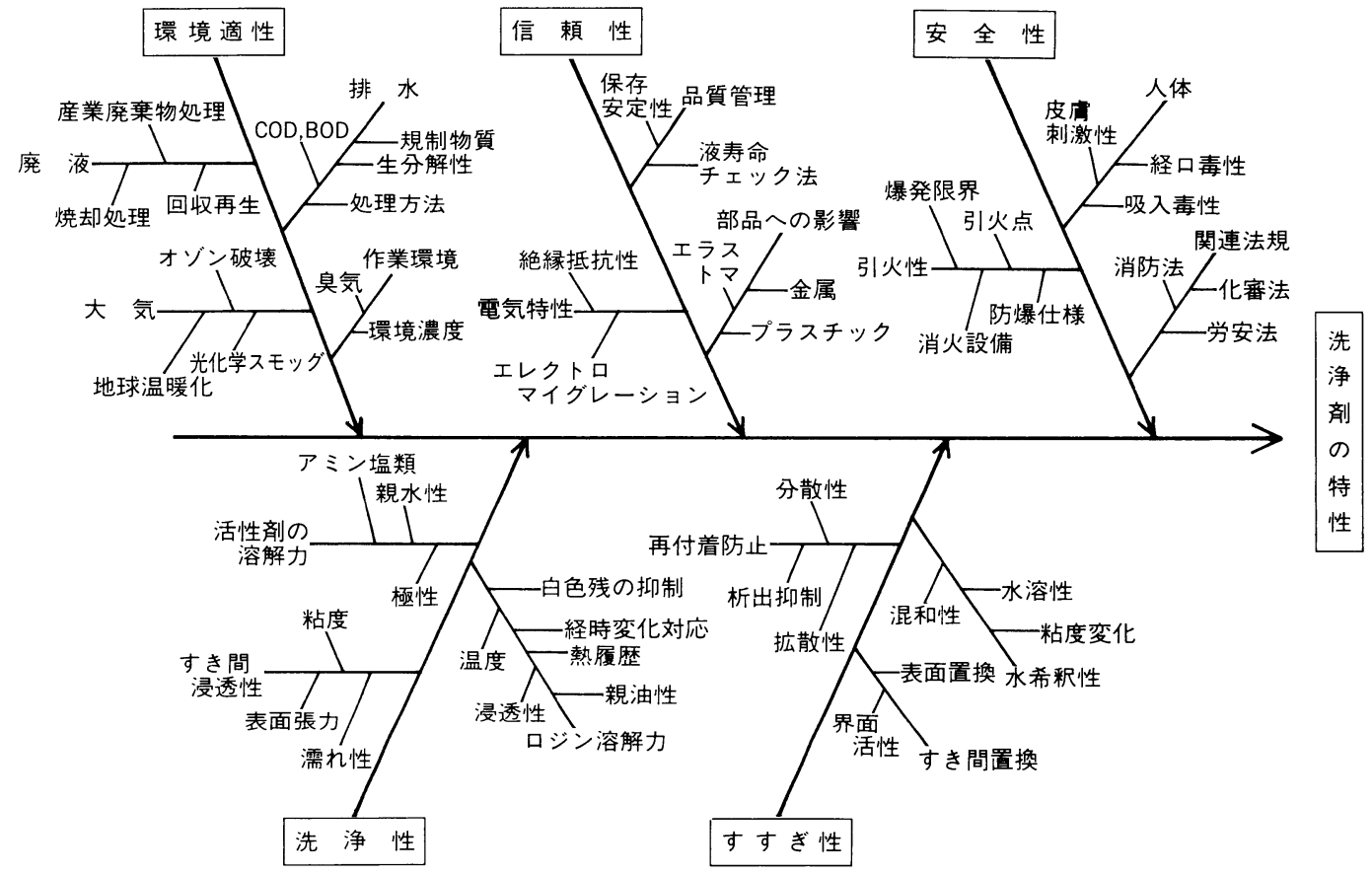

図 2.非ハロゲン系洗浄剤の特性要因図

洗 浄の”仕組み

主要な成分

水混和性のタイプ

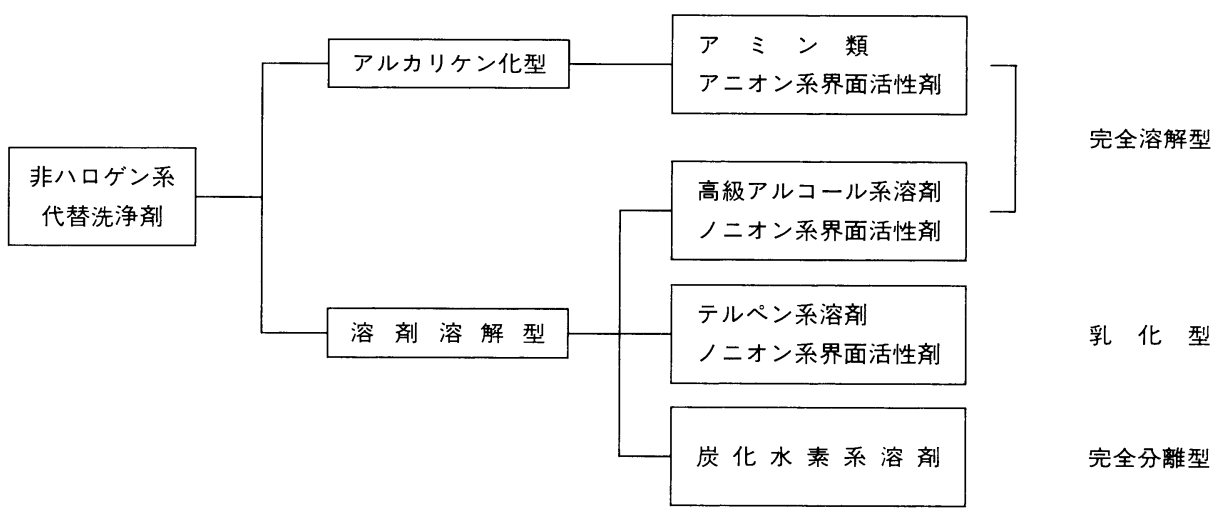

図 3 . 非ハロゲン系洗浄剈の分類

剤の主要成分について述べる。

基板上に固着するフラックス残渣の洗浄では，ま ずバインダーとして機能するロジン系樹脂を溶解す ることが必要である。この溶解の仕組みから，図 3 に示すように，すでに提案されている多数の洗浄剤 は 2 つのタプに分類できる。

\section{4・アルカリケン化型洗浄郕}

1つは,アルカリケン化型と呼ばれアミンを主要
な成分とする水溶液であり, $\mathrm{pH}$ が高いという特徵が ある。このタイプの洗浄の仕組みは，ロジン系樹脂 のカルボキシル基とアミンの中和反応を利用して, ロジン系樹脂を水溶性のアミン塩に変換した上で除 去している。したがって，塩基性の強いアミンを用 いてその濃度を高くするほど強い洗浄力が得られる が，一方はんだなどの金属表面や部品の印刷インキ への侵食性も増大し，はんだの変色やッヤ引けを起 こしたり, 部品の型番表示が消失する傾向もある。 
これらの問題のバランスを取るために，アミンは低 濃度に抑えられているが, フラックス残渣の溶け込 みにより有効なアミンが消耗するため, 洗浄時には $\mathrm{pH}$ 管理を行う必要がある。また $\mathrm{pH}$ の管理幅は予想 外に狭く,さらに数\%のフラックス残渣の蓄積で洗 浄液の交換が必要といわれている。

使用する上での利点としては, 非危険物で消防法 上の規制を受けることなく，また洗浄機の洗浄槽に 塩ビなどの安価な素材が使用できるため, 低コスト の洗浄機が実現できることにある。ただし，すすぎ 水の排水処理は, 現在のところ活性炭を用いる吸着 処理しかなく，ランニングコストや必要なメンテナ ンスを事前に十分検討することが肝要である。また, 使用済みの洗浄廃液の処理についても, 新たな公害 を防止するために経済的で有効な手段を早急に見い だす必要がある。

\section{5. 溶骫溶解型洗浄骫}

2 つめのイプは, ロジン系樹脂を溶解する有機 溶剂を主要成分とするもので, 用いる溶剂の種類に よりさらにいくつかタイプに分類できるが, ここで は特性に大きな違いのある 3 種に分けて述べる。

はじめに高級アルコール系溶剤と界面活性剤を主 成分とするタイプは, 先のアルカリケン化型と同じ く，すすぎに使用される水に完全に溶解する性質を もっている。2 番目のテルペン系溶剤と界面活性剤 に代表されるタイプでは，水に乳化状態で分散する。

3 番目の炭化水素系溶剤では, 水に分散することな く，完全に油水分離する性質をもっている。

\section{1 高級アルコール系洗浄阂}

アルカリケン化タイプと比較して, 溶剤溶解型に は引火性があり, 安全対策のために洗浄機が高価に なること，および非希釈夕イプであり，すすぎ水の $\mathrm{COD}, \mathrm{BOD}$ 值が高く, 排水処理の負担が大きいな どといった問題点があるが, 高級アルコール系では, 水と任意の比率で混じり合う性質を利用して, 消防 法上の危険物に該当しない ${ }^{1}$ 非引火型も開発され，表 1 のごとくアルカリケン化タイプに対する溶剤溶解 型の最大のデメリットが解決されている。また図 4 に示すように, 従来のフロン洗浄よりはるかに小さ なイオン残留率を達成でき, 洗浄剤中のフラックス
表 1. 高級アルコール系洗浄剤の一般物性 ${ }^{2), 3}$

\begin{tabular}{|c|c|c|c|}
\hline & 高級アルコール系 & テルペン系 & CFC-113/EtOH系 \\
\hline 外 & 無色透明 & 淡黄色透明 & 無色透明 \\
\hline 臭 & 微 臭 & 柑 橘 系 & 微 臭 \\
\hline 粘度 $\left(\mathrm{cp}, 20^{\circ} \mathrm{C}\right)$ & $4^{*}$ & 1 & 1 以下 \\
\hline 比 & 0.96 & 0.84 & 1.50 \\
\hline${ }^{\text {比 }}\left(\mathrm{Cal} / \mathrm{g} \cdot{ }^{\circ} \mathrm{C}\right)^{\text {熱 }}$ & 0.693 & - & 0.213 \\
\hline 凝 固 点 $\left({ }^{\circ} \mathrm{C}\right)$ & -20以下 & -20 以下 & -20以下 \\
\hline $\begin{array}{l}\text { 表 面 張 } \text { 力 } \\
\left(20^{\circ} \mathrm{C}, \mathrm{dyn} / \mathrm{cm}\right)\end{array}$ & 31.0 & 33.0 & 18.0 \\
\hline 水 溶 & 完全溶解 & 乳 化 & 分 離 \\
\hline 引 火 点 $\left({ }^{\circ} \mathrm{C}\right)$ & なし & 47 & 不燃性 \\
\hline 消 防 法 & 非危険物 & 第 2 石油類 & 非危険物 \\
\hline $\mathrm{LD}_{50}(\mathrm{mg} / \mathrm{kg})$ & 6100 & - & - \\
\hline 審 & 既存化学物質 & 既存化学物質 & 既存化学物質 \\
\hline 労 安 & 非該当 & - & - \\
\hline
\end{tabular}

* $50^{\circ} \mathrm{C}$ で測定

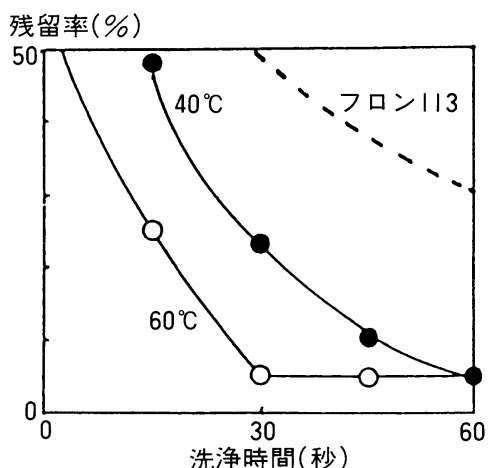

残留率 $=\frac{\text { 洗浄後の残留イオン濃度 }}{\text { 洗浄前の残留イオン濃度 }} \times 100$

フラックス (LONCO Resin Flux \#77-25)/260 ${ }^{\circ} \mathrm{C}, 5$ 秒 純水すすぎ : $60^{\circ} \mathrm{C} / 1$ 分 $+25^{\circ} \mathrm{C} / 1$ 分

\section{図 4.高級アルコール系洗浄剤における 洗浄時間とイオン残留率2)}

濃度が $20 \%$ に達しても, 図 5 のごとく絶縁抵抗の長 期信頼性に影響を与えないといった洗浄剤としての 優れた耐久性を有している。これは，高級アルコー ル系洗浄剤がロジン系樹脂に対し高い溶解力をもつ とともに，すすぎ性の良さをも兼ね備えている結果 といえる。さらに, 他の溶剤溶解型洗浄剤と比べ極 性が大きく，かつ水溶液であるため，フラックス活 性剤（たとえばジメチルアミン塩酸塩）に対して， 洗浄剂自体が溶解性をもっていることも大きな特徴 である。この特性によって，すすぎ水の乾燥が困難 な基板に対して, 非水系のリンス剤, たとえば 5 - 


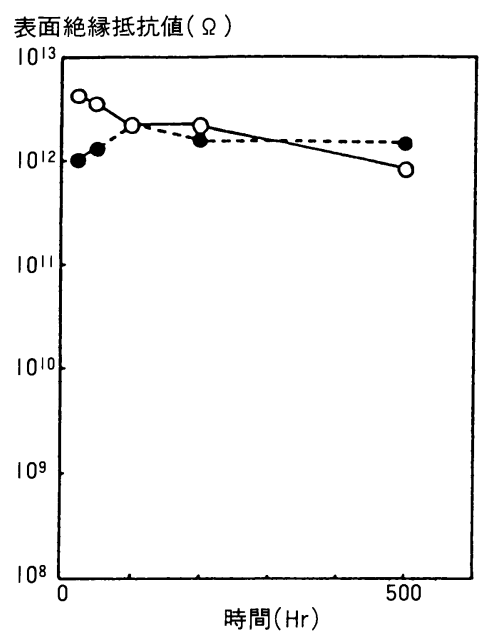

$$
\begin{aligned}
& \text { フラックス含有量 } \quad(\mathrm{O}): 0 \% \quad(\mathbf{O}): 20 \% \\
& \text { くし形電極 } \mathrm{B} \text { パターン }(0.636 \mathrm{~mm} \text { ピッチ) } \\
& 85^{\circ} \mathrm{C}, 85 \mathrm{RH} \%, \mathrm{DC} 12 \mathrm{~V} \text { 印加 }
\end{aligned}
$$

図 5 . 高級アルコール系洗浄剤における 長期信頼性とフラックス蓄積の影響

フッ化プロパノールを用いても，図 6 のように残留 イオン濃度を小さくできる。

今後の課題は, すすぎ水の排水処理であるが，固 定床式の活性污泥処理が有望とされており，コンパ クトで経済的負担の少ない処理装置の開発が進めら れている。

\section{2 テルペン系洗浄凮}

次にテルペン系の洗浄剤の場合，主成分の $\mathrm{d}-リ モ$ ネンが高い溶解力をもつものの引火点が低いため, 防爆仕様の洗浄機が必要で, 状況によっては同一区 域内の周辺機器すべてに防爆対策を施さなければな らない場合もある。これに対応する形で， d-リモネ ンを高引火点の第 3 石油類相当の溶剤に置き換えた タイプも提案されているが，いずれも引火性の危険 物であり安全対策が必要である。

また，すすぎ水とエマルジョンを形成する性質は， すき間部分のすすぎ性に問題が残る。すなわちすき 間にたまった洗浄剤にすすぎ水が混入していく過程 を考えると, 油中水滴型の $\mathrm{w} / \mathrm{o}$ エエマルジョンから 水中油滴型の $0 / \mathrm{w}$ エマルジョンに反転することが 必要であるが, この反転時には通常, 流動性の喪失 がみられる。すき間部分では，洗浄液に加えられる スプレーや液中ジェット，あるいは超音波といった 機械的な力は期待できず, 部品下にすすぎきれない

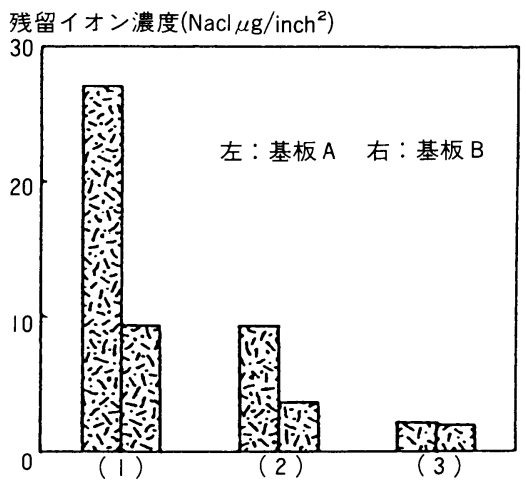

(1) フロンのみ

煮沸下, 超音波洗浄 3 分 $\rightarrow$ 蒸気洗浄 1 分

(2) 高級アルコール系洗浄剤 + $5 \mathrm{FP}$ リンス $60^{\circ} \mathrm{C}$ 超音波洗浄 3 分 $\rightarrow 60^{\circ} \mathrm{C} 5 \mathrm{FP}$ 浸漬 1 分

(3) 高級アルコール系洗浄剂 + 水リンス + 5 FP水切り $60^{\circ} \mathrm{C}$ 超音波洗浄 3 分 $\rightarrow$ 室温水すすぎ 3 分 2 回 $\rightarrow 60^{\circ} \mathrm{C} 5 \mathrm{FP}$ 浸漬 1 分

図6.高級アルコール系洗浄剤における リンス剤と残留イオン濃度 ${ }^{2}$

洗浄剤が残る可能性が大きい。洗浄剤とフラックス の活性剤，そして水分が基板上に残留するとエレク トロマイグレーションの原因となり, 回路の断線や 短絡といった重大なトラブルも懸念される。

テルペン系洗浄剤には, 開発の原点として d-リモ ネンを有効利用しようとの発想があるように思われ る。米国での使用実績はあるものの，表面実装や高 密度化で先行している日本においては, 洗浄対象基 板との適合性を十分吟味する必要がある。基本的な 溶解力が高い利点を生かし，実装密度がそれほど高 くない基板を小規模に洗浄する場合などに実用化さ れるであろう。

\section{3 炭化水素系洗浄風}

最近, 水とまったく混和しない夕イプの洗浄剤が 提案されている。界面活性作用や水溶性の成分を除 外した炭化水素系溶剤のみの構成で, すすぎ水の排 水処理を油水分離で対応しょうとの試みである。洗 浄する規模が比較的小さく，排水処理装置への設備 投資が困難な場合に有用なタイプと思われるが，す すぎ性が低く洗浄の品位からみた使用領域は限定さ れる。

基板上の部品やレジストの表面は蹯水性で，同じ く疎水性の洗浄剤にいったん濡れると，水に簡単に は置換されない。したがって，フラックスを含む洗 


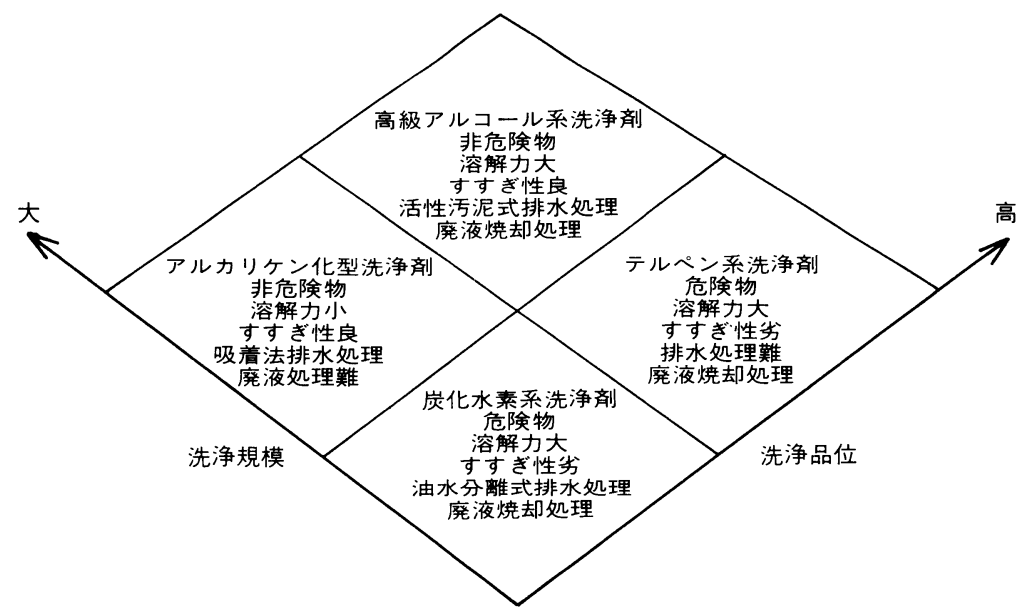

図 7 . 非ハロゲン系洗浄剤の特徵と洗浄の規模と品位からみた適応領域

浄剂はすすぎ後も基板表面に薄い被膜状に残り，高 度な長期信頼性が要求される基板には使用できない。 また洗浄基板の清浄度が洗浄剤中のフラックス濃度 の影響を強く受けるため, 交換までの洗浄剤の寿命 も比較的短いと思われる。

このタイプの洗浄剤は, 排水処理の容易さから, たとえば無洗浄フラックスへの転換と競合する種類 の基板を小型の洗浄機で洗浄する場合などに, 実用 化される可能性がある。

\section{6. 洗浄棛の位置付け}

以上, 実装基板の洗浄剤を 4 つのタイプに分類し て述べたが, それを選択するにあたっては, 導入時 に予想される初期投資額やランニングコスト，また 目標とする残留イオン濃度などの清浄度, さらには 被洗浄物に対する適性などを考慮する必要がある。

各洗浄剤の特徵から, 洗浄基板の目標である目視 の清浄度や残留イオン濃度, 長期信頼性などの洗浄 品位の高低と, 必要な洗浄機の大きさや処理量など の洗浄規模からみたそれぞれの適性な領域を図 7 に まとめた。図では,これら洗浄剤の相対的な位置関 係のみを示し, 各領域の大きさは無視している。

\section{7・おわりに}

コンピュータの主要基板の洗浄など, 高い清浄度 が要求される領域においては, 目標を達成するため にフロン洗浄の後にさらに純水洗浄を加える対応が 行われてきた。実装基板のフラックス洗浄は, フロ ン問題に端を発したものの, 高密度化や表面実装の 今後の進展を考えると, 今やフロン洗浄に代わるよ り高度な洗浄技術の革新が求められているといえる。 そして, それには洗浄剤の開発にとどまることなく, 安全に, 安定した洗浄品質が得られ, かつ環境に負 担をかけない洗浄機や洗浄液管理法, 排水処理法な ぞのシステムとしての開発が不可欠である。

\section{交献}

1）危険物保安技術協会：“危険物等データベース”, 登録番号9994X002575

2 ) インターネプコンジャパン'91配布, 荒川化学工業技 術資料 “パインアルファST-100シリーズ”

3 ）荒川化学工業説明資料 “PINE ALPHA ST-900シ リーズ” 